\title{
Euromaidan and conflict in Eastern Ukraine in social networking sites: Territorial differences of pro-Russian subscriptions in Ukraine
}

\author{
MyкоLA DOBYSH ${ }^{1}$
}

\begin{abstract}
Securitization of cyberspace is of great geopolitical concern. Behaviour on the Internet is not diminishing the influence of existing borders but can polarize society along territorial divisions. The paper explores territorial differences in the subscription to public pages and open groups in social networking sites (SNS), which emerged as a reaction to revolutionary events in Ukraine (known as Euromaidan or Revolution of Dignity) in 2013-2014 and Russia-backed armed conflict in the East of the country. The findings show differences in subscription to such pages in Vkontakte (the most popular SNS in Ukraine before a ban in 2017) among citizens of Ukraine and Russia, regional centres in Ukraine, cities in uncontrolled by Ukrainian government territories, reclaimed by Ukrainian army territories, territories of Lugansk and Donetsk regions which were not under substantial control of Russia-backed separatists, and peripherial cities of the neighbouring Kharkiv, Dnipropetrovsk, and Zaporizhya oblasts. The paper also analyzes the geopolitical narratives of pro-Russian public pages in Vkontakte and shows how SNS could be used as a geopolitical tool.
\end{abstract}

Keywords: securitization of cyberspace, Euromaidan, conflict in Eastern Ukraine, social networking sites

\section{Introduction}

Social networking sites (SNS) are new battlefields of different political beliefs and preferences, geopolitical narratives and imaginations, attitudes towards conflicts and political and social contradictions. In Ukraine, the revolutionary events of 2013-2014 (known as Euromaidan or Revolution of Dignity) and armed conflict in Donbas resulted in many new public pages and groups in Vkontakte, Facebook, Odnoklasniki, and Twitter. Despite the opportunity to get a variety of information sources and directly communicate with opposing side of the conflict, which might have mediation and democratization effects, the practices of using SNS resulted in polarization of the society and formation of more profound cleavages. Public pages and open groups, which were covering events on the
Maidan in Kyiv during the Revolution and later Russia-backed armed conflict in Donbas, were producing not only news reports. They started to propose a broader vision of the conflict, geopolitical narratives about enemies and friends (the US and NATO, European Union, Russia), new division lines between "Us" and "Them", legitimating and delegitimating narratives about political centres (Kyiv and Moscow) and relations to them, and geopolitical picture of the world. Moreover, Russian Federation involvement in the conflict was also supported by active information campaigns in SNS discrediting Ukraine as an independent state, de-legitimating new Ukrainian government, and promoting separatist movements within the country. It resulted in a ban of Russian SNS (Vkontakte and Odnoklasniki) in Ukraine as well as many other Russian websites in 2017.

\footnotetext{
${ }^{1}$ Department of Geography, Taras Shevchenko National University of Kyiv, Glushkova Avenue 2A, Kyiv, Ukraine. E-mail: mpetrovych@gmail.com
} 
The use of SNS as a geopolitical tool often results in polarization of the society and raises a question about securitization of cyberspace. Such polarization has its territorial dimension. The intensity of the conflict in Ukraine strengthened not a nation-wide network of connections in SNS but regional (Duvanova, D. et al. 2016). The paper focuses on the manifestation of Ukrainian Revolution of 2014 and armed conflict in Donbass in SNS and aims to reveal territorial differences in the spreading of Russian geopolitical narratives and pro-Russian position in the conflict as well as differences between social networks in the representation of the events. In the first part, it shows the current state of research on political behaviour in SNS. The second part presents the methodology and data of the study. The third and fourth parts analyze territorial differences of choosing information sources in SNS in Ukraine, and the fifth part is dedicated to the content analysis of geopolitical narratives by pro-Russian public pages in Vkontakte.

\section{Political behaviour in social networking sites}

The use of the Internet brings new challenges to political geography research. FrIEDMAN, Th.L. (2005) states that in such conditions space is concerning place, which could be understood as making places obsolete and erasing territorial differences in political and social phenomena. However, GoldenberG, J. and LeVY, M. (2009) empirical study suggests that new technologies are not undermining the uniqueness of places and influence of distance but even could emphasize them. Moreover, seemingly uncontrolled communications on the Internet are of geopolitical concern (Pinkerton, A. et al. 2011). One of the cases of this absence of control is the inability of nation-states to control the flow of information within their borders (especially in conflict situations). However, the ban of Russian websites and Vkontakte and Odnoklasniki SNS in Ukraine in 2017 is an example of how state government could impose control over the information space of the country. The paper argues for the examination of these "emergent arenas of securitization" (Bernazzoli, R.M. and Flint, C. 2009). Moreover, SNS are increasing their role in "popular production of geopolitical knowledge" (Pinkerton, A. and Benwell, M. 2014), which should be reflected in political geography studies.

On the one hand, SNS open access for the broader population to the same sources of geopolitical narratives (passing existing territorial borders) and contribute to bottom-up participation in their shaping. On the other hand, geopolitical actors receive a powerful instrument to spread their geopolitical imaginations and frame social and political issues in their interest. In such a case, political beliefs and geopolitical imaginations of particular places can be shaped by the politics of interested geopolitical actors - still, the question what territories are more vulnerable to such influences and why remains open.

Current research on political issues in SNS is focused on active use of them in electoral campaigns in different countries of the world (Kasmani, M.F. et al. 2014; Kruikemeier, S. 2014; Steenkamp, M. and Hyde-Clarke, N. 2014; Frame, A. and Brachotte, G. 2015), political mobilization of population for the action and participation in politics (NAM, T. 2012; PARK, CH.S. 2013), and correlation between online membership and offline engagement (Conroy, M. et al. 2012). However, it is essential that not only SNS change political behaviour but also places shape people's behaviour on the Internet and the use of social networking sites (WANG, D.M. et al. 2016). For instance, existing empirical studies reveal that Twitter networks are dependent on the geographical distance between users (TAKнteYeV, Yu. et al. 2012) and SNS users cluster themselves in politically homogeneous networks (Borondo, J. et al. 2014). JACKson, L. and VALEnTINe, G. (2014) assume that such computer-mediated communication is a new way of doing politics through its absence and presence at the same time. Therefore, SNS are a new political and geo- 
political instrument of influence, and, at the same time, their use is framed by the existing territorial differences.

We suggest that SNS not only work as registration of reality but also produce it and are a form of symbolical violence as Bourdieu, P. (1998) stated about television. Lippmann, W. (2017) suggests that social media influence on public opinion has two crucial aspects: (1) filtration of reality, and (2) focus of attention on prepared facts, which are understood as worked out by political actors, media, opinion leaders and other subjects engaged in and interested to influence public opinion. In case of public pages and open groups in SNS that emerged as a reaction to revolutionary events in Ukraine in 2013-2014, they were not only focused on prepared facts but also produced fake news and manipulated information for the sake of one side of the conflict. Consequently, SNS did not bridge political divides in Ukrainian society but polarize them further during the conflict (Duvanova, D. et al. 2015).

Social media and social networking sites also became part of soft power and public democracy strategies by geopolitical powers (Simons, G. 2015). As a seemingly uncontrolled channel of information, SNS became essential tools in the formation of alternative geopolitical narratives of conflicts, geographical imaginations about particular places and regions and their relations to political centres, a geopolitical picture of the world and relations between countries. Social media operations are an essential part of Russian propaganda in Eastern Europe (Helmus, T.C. et al. 2018). Russia was using social networking sites in Ukraine to frame its geopolitical messages (Gaufman, E. 2015). Historical myths, regional identity, and images of the enemy were exploited by the Russian Federation in spring 2014 in the Donbas region to escalate conflict (Osipian, Al.L. 2015). Therefore, territorial differences of the use of SNS in Ukraine during 2013-2014 revolutionary events and later during the armed conflict in Donbas are not only caused by internal factors and known regional differences in political preferences and voting behaviour in Ukraine (Liber, G.O. 1998; BiRCH, S. 2000; O'Loughlin, J. 2001; BARRINGTON, L.W. and Herron, E.S. 2004; Clem, R.S. and Craumer, P.R. 2008; Osipian, Ar.L. and Osipian, Al.L. 2012; Peisakhin, L. 2013; O’Loughlin, J. et al. 2016), but also external involvement and mobilization of the population of Ukraine to reach geopolitical goals. Therefore, the paper is mainly focused on Russian SNS, subscription to pro-Russian public pages, and geopolitical narratives produced by them to examine territorial differences of the consumption of that content.

\section{Data and methodology}

Data was collected using publicly available information in Vkontakte, Facebook, Odnoklasniki, and Twitter SNS. Using search option for these SNS we found the number of public pages and groups, which have used such words as "Euromaidan", "Antimaidan", "Ukrainian Revolution", "Novorossiya", and "ATO" (Anti-terrorist operation) in their names, which shows their dedication to the revolution in Ukraine in 2013-2014 and armed conflict in Donbass. A number of subscribers/members was also received from publicly available information in search engines. Vkontakte was chosen as a case study for territorial differences in choosing information sources because it was the most popular SNS among Ukrainians in 2015 (11.8 million of individual user profiles in 2015 according to Gemius) and most politicized and polarized according to our preliminary study.

Vkontakte has a built-in instrument of filters, which gives the opportunity to filter subscribers of chosen public page or group by location, age, education, gender, image status, and other parameters filled in personal account settings. Some of the parameters are filled in the process of registration (hometown, age, and gender); therefore, all profiles have that information. It is important that location in Vkontakte is not presented as the user's current place of living but as a 
hometown, which is a matter of choice by the user itself. Vkontakte has security settings, where the user can make information unavailable for the public. However, hometown and gender are open for filter instrument. For the purposes of this paper, information about the number of subscribers to top-5 ideologically opposite public pages and groups was collected for Ukraine and Russia in general, administrative centres of Ukrainian oblasts (regions), and for the case study cities in the conflict territories and neighbouring regions in Eastern Ukraine.

Vkontakte search instrument also allows filtering profiles by hometown. This feature was used for the second part of the study, which focuses on the conflict territories and neighbouring regions in Eastern Ukraine. For the research purposes we identified four different areas in the Eastern Ukraine: (1) uncontrolled by Ukrainian government, (2) reclaimed by military actions after occupation, (3) territories of Donetsk and Lugansk oblasts, which were not under substantial control of Russia-backed separatists, (4) periphery of the conflict zone in the neighbouring regions. For each of these areas we chose two (in case of neighbouring regions three because three oblasts are neighbouring Donetsk and Lugansk oblasts) comparable cities. For each of them, we used systematic sampling with gender quota. In the search window filtered by location, each randomly defined $\mathrm{n}$-profile from general sample $\mathrm{k}$ was chosen to reach the quota of 25 male and 25 female profiles. Data about gender composition of the Internet audience of the chosen cities was unavailable; as a result, the equal number of males and females was chosen, which we should admit slightly differs from the actual composition of the population of the cities.

Consequently, in nine cities sample of 450 profiles was selected for the analysis of the behaviour in SNS: posts and reposts of political content, subscription to public pages with political content, membership in groups dedicated to political issues. Political issues were narrowed down to the Euromaidan revolution, the annexation of Crimea, and conflict in Donbass. Due to personal security settings, not all information was publicly accessible. Subscription to public page information was available for all the profiles, while information about membership in groups and posts and repost was limited only to those profiles, which did not make that information private. Our study revealed that in 30.4 per cent of cases (134 out of 450 ) people make the list of the groups they are members unavailable for the public.

The third part of the research was based on the data from two of the five most popular Antimaidan, pro-Russian, and pro-separatist public pages and groups: "Antimaidan" and "Russkie online - Novorossiya". The first one appeared as opposition to the revolutionary events in Ukraine in 2013-2014 and the second one as a promotion and support for the separatist movement in South-Eastern Ukraine. 1053 news posts from "Antimaidan" and 756 posts from "Russkie online - Novorossiya" were chosen for the content analysis. These posts include all, which were made on these pages in Vkontakte from March 10 to March 25, 2015, following a military escalation in January, Second Minsk Agreements in February, and the start of the positional armed confrontation. The content of all posts was coded into four groups: (1) about Ukraine, (2) in relation to Russia, (3) about the US and EU, and (4) Other. It was also decided to include armed conflict news posts as a category in the group "in relation to Russia" because they were done from the Russian perspective and often addressed the Russian government. Within these four groups, messages and framing of political events was coded into subgroups, which are presented and discussed in the last part of the paper.

We are aware of the limitations of the paper. It is focused only on the sources of the information people chose in Vkontakte during Euromaidan and conflict in the East of the country, which in some cases might not represent that people share geopolitical narratives and political beliefs of those public pages and open groups. However, the share of subscription to ideologically oppo- 
site public pages in the total subscription to sources of information about Euromaidan and conflict reveals biased predominance or overweight of subscription to one of the sides of the conflict in particular areas. The paper has no examination of public pages, which had balanced position covering conflict events because it was one of the effects of SNS - emerged public pages and groups were emphasizing differences and not building bridges. Moreover, the data was collected after the period of the escalation of the conflict in February 2015, which should be taken into consideration interpreting the results of the study. The focus of the paper is on proRussian public pages and their geopolitical narratives because Russia is increasing its geopolitical presence in the world using SNS as geopolitical tools. The paper uses a concept of territorial differences, and we are cautious that obtained data is for particular cities.

\section{Territorial differences in support of the Euromaidan Revolution in Ukraine in SNS}

In November 2013, president of Ukraine, Viktor Yanukovych, refused to sign the Association Agreement with the EU during Eastern Partnership Summit in Vilnius despite public pressure in Ukraine. It caused protests and polarization of society. Subsequent events show the fundamental foreign policy cleavage in Ukraine, which supports Lijphart, A. (see Johnston, R.J. et al. 1990) complementation of the classical LiPSET, S.M. and RoKKAN, S. (1967) model. Two main social movements emerged as a reaction to the events in Vilnius and Kyiv: Ukrainian revolution (Euromaidan or Revolution of Dignity) and Antimaidan. In the course of events, the annexation of Crimea and Russia-backed armed conflict in Donbass resulted in the additional line of confrontation in society: pro-Ukrainian support of sovereignty versus the pro-Russian support of separatists, Novorossiya concept, and unity with Russia. However, in Ukraine, foreign policy cleavage is complicated by active Russian involvement.
The manifestation of the "Euromaidan" revolution and war in Donbass in SNS

As the Euromaidan and Antimaidan movements started in 2013, they were actively discussed in social networking sites. Figure 1 shows that thousands of public pages and groups emerged to report news and opinions on the ongoing conflict. Public opinion was divided into two camps: (1) supporters of the Euromaidan, and (2) opponents. SNS also followed that line of divide and pages where information was presented only from one of the points of view were created and actively promoted. Russian propaganda was also actively engaged in the process. For instance, two Russian social networking sites, Vkontakte and Odnoklasniki, were platforms were most of the pages criticizing Ukrainian pursuit for European integration and later supporting separatist movements and annexation of Crimea emerged. At the same time, only Odnoklasniki is dramatically one-sided in the number of pages and subscribers for Antimaidan and pages supporting separatism and unity with Russia.

Facebook is in the opposite pole, with most of the popular pages and their subscribers being pro-Ukrainian and pro-European in the coverage of the conflict. Twitter is less popular in Ukraine and had a balanced number of pro-Russian and pro-Ukrainian pages. Numbers show that despite many channels of information created to spread the pro-Russian view of the conflict; they were not so popular. Vkontakte is the most polarized SNS among analyzed. Top-5 public pages with pro-European and proUkrainian stances have near two million subscribers and members, while top- 5 proRussian pages have one million and a half. Vkontakte also was the most popular SNS in Ukraine and the most representative of the the Ukrainian internet audience in 2013-2017. In 2017, Vkontakte, as well as Odnoklasniki and many other Russian media, were banned in Ukraine as a part of the measures to counteract Russian aggression and propaganda (Figure 1. and 2). 

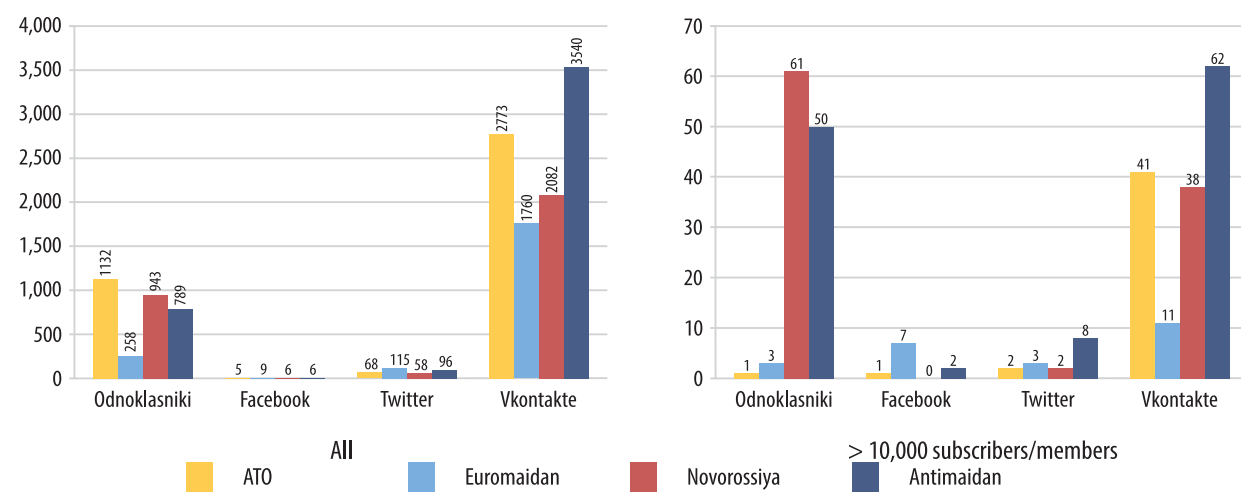

Fig. 1. Number of groups and public pages in popular social networking sites dedicated to the Ukrainian revolution of 2013-2014 and war in Donbass by keywords used in the name.

Moreover, the politicization of the citizens of the Russian Federation and their engagement in an online confrontation over the Euromaidan, lately annexation of Crimea and war in Eastern Ukraine are vivid. All the top-5 pro-Russian, Antimaidan, and pro-separatist pages and groups have the majority of subscribers from Russia, not from Ukraine (Figure 3). At the same time, top-5 pro-Ukrainian sources of information in Vkontakte have 99 per cent and more subscribers from Ukraine. Therefore, the conflict manifestation in Vkontakte shows that it was not only within Ukraine but had a clear Russian involvement.

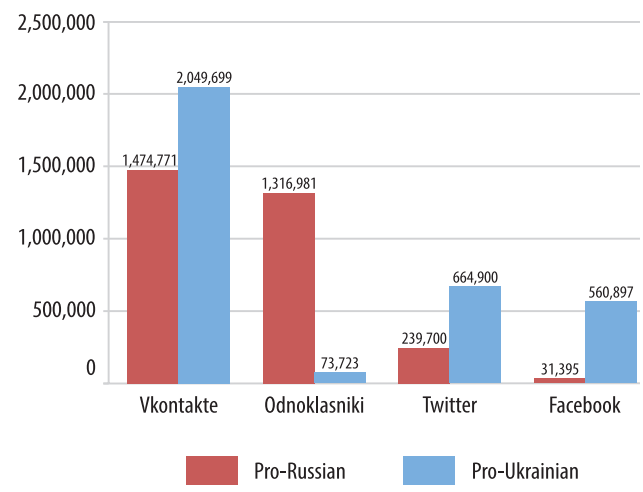

Fig. 2. Number of subscribers and members of top-5 ideologically opposite public pages in popular social networking sites in Ukraine, 19 February 2015.
Territorial differences of subscription to ideologically opposite public pages and groups in Vkontakte

Until Vkontakte was banned in Ukraine in 2017, it was the most popular SNS. It is the most representative of the polarization of political views among Internet users in Ukraine. In Donetsk, Lugansk, and Simferopol subscribers to pro-Russian, pro-separatist, and Antimaidan pages dominated pro-Ukrainian (more than 83 to 17). Only in Kharkiv and Odessa in South-Eastern Ukraine they had a substantial share in the total subscription to top-10 ideologically opposite public pages and groups (38\% and 33\% correspondingly). In Mykolaiv, Kherson, Zaporizhya, and Dnipro, regional centres of South-Eastern Ukraine, the shares of subscribers to pro-Russian sources of information were only from 15 per cent to 24 per cent. 8 per cent of pro-Russian subscriptions in Kyiv stands out of Central Ukraine. While in Central and North-Eastern Ukraine pro-Russian sources of information in Vkontakte had only 2-6 per cent share. In Western Ukraine, pro-Ukrainian sources of information in Vkontakte totally dominated (98-99\% of subscriptions) (Figure 4).

Consequently, easy access to different viewpoints and sources of information on the Internet does not erase territorial differences in political beliefs. Moreover, it creates pre- 

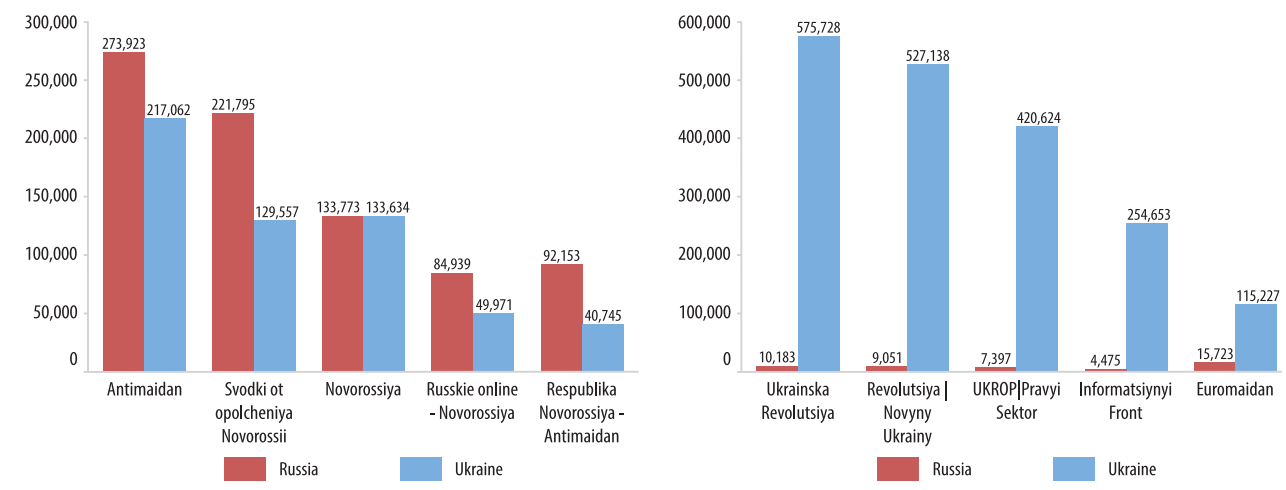

Fig. 3. Number of subscribers and members of top-5 ideologically opposite public pages/groups in Vkontakte by country of origin, 19 February 2015.

conditions for polarization and territorially framed preferences for information sources. For such powerful geopolitical actors as Russia, it opens the door for the informational involvement in the creation of symbolical reality and geopolitical imaginations of people in foreign countries. Primarily this is the case in the neighbouring countries where there is no language barrier, and a shared history could be used as an instrument for unification under one centre position and disunion with the other.

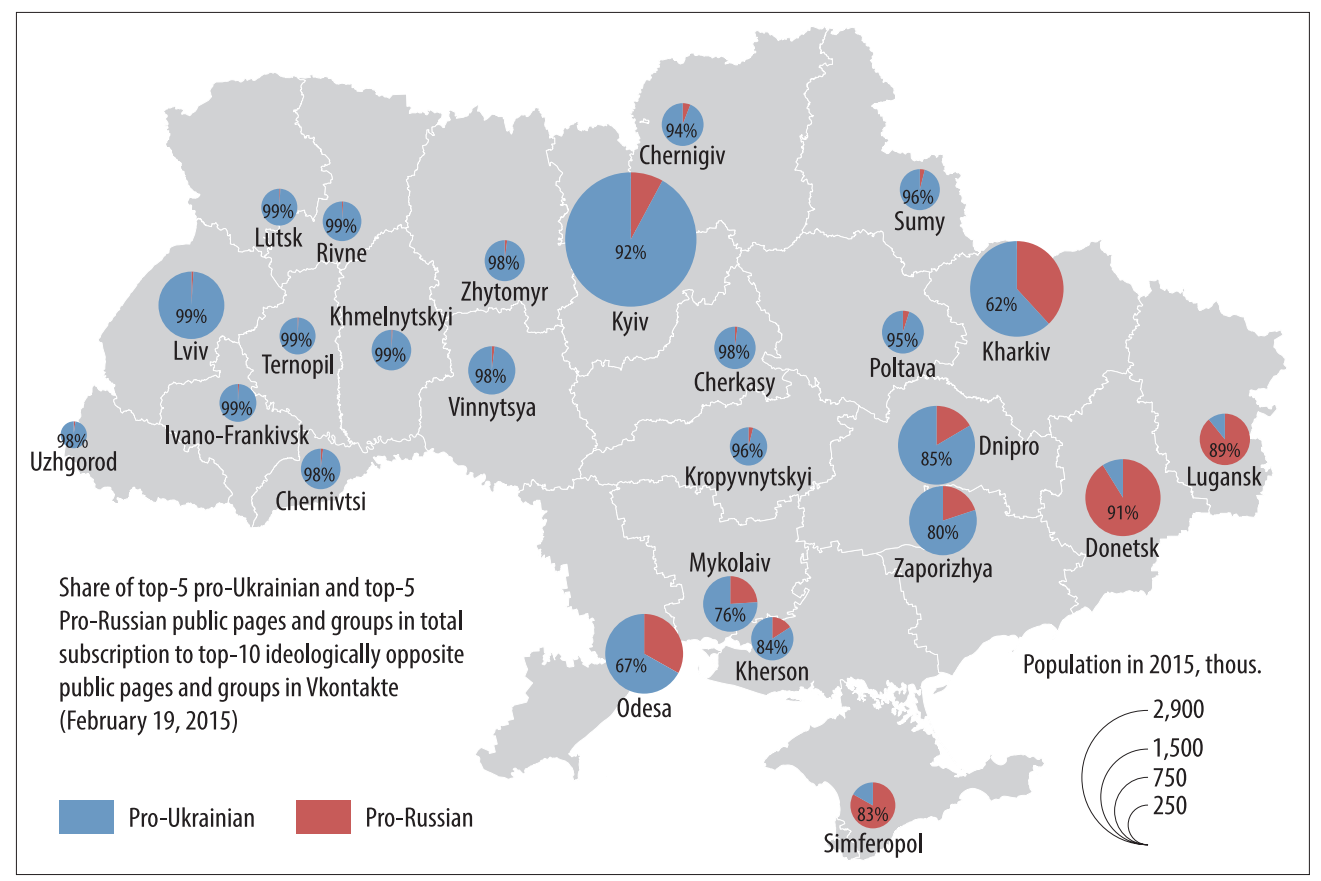

Fig. 4. Territorial differences of subscription to top-10 ideologically opposite public pages/groups in Vkontakte, 19 February 2015. 


\section{Conflict in Eastern Ukraine and territorial differences of political behaviour in SNS}

After the annexation of Crimea and the start of the war in Eastern Ukraine, the Internet users and Vkontakte members faced the question of reliable sources of information about the events. However, it turns out that the question was rather about suitable sources of information or those that arise due to socialization in particular geographic places. Our study of Vkontakte shows that assumption that space is conquering a place in the era of new technologies (Friedman, Th.L. 2005) is not the case in choosing sources of information about conflicts. Four studied areas in Ukraine show differences in sources of information about Euromaidan revolution and conflict in Eastern Ukraine. In uncontrolled by Ukrainian government territories subscription to top-5 pro-Russian public pages and groups prevailed. Subscription to top-5 pro-Russian public pages is 26.9 per cent in Yenakiieve and 16.3 per cent in Kadiivka (Stakhanov), while a subscription to pro-Ukrainian pages is only 0.70 and 0.85 per cent, respectively (Table 1). It was predominant in the reclaimed territories of Bakhmut (Artemivsk) in Donetsk oblast and Lysychansk in Lugansk oblast but with lower numbers of subscription $(12.0 \%$ and $9.7 \%$ respectively).

In territories of Donetsk and Lugansk oblasts, which stayed under Ukrainian government control during the conflict, the numbers of subscription to top-5 pro-Russian public pages and groups was even lower $(9.7 \%$ in Pokrovsk [Krasnoarmiysk] and 8.0\% in Starobilsk), while the use of pro-Ukrainian sources of information was higher $(2.5 \%$ and $2.7 \%$ respectively). In the periphery of the neighbouring regions, subscription to top- 5 pro-Ukrainian public pages and groups was already higher than to top-5 pro-Russian (except Izium city in Kharkiv oblast were it was almost equal).

The second part of the study of the conflict territories of Eastern Ukraine sources of information about the conflict included a sample of 450 profiles from studied cities and not only subscription to top-5 ideologically opposite public pages from each side of the conflict, but also other groups and pages and reposts of the information on personal pages feed. As shown in Figure 5, the numbers of people who used polarized sources of information about the conflict were even higher, but patterns of the information sources in four studied territories of Ukraine were the same. In profiles from uncontrolled territories, the use of pro-Russian sources of information was predominant; in reclaimed territories, they were substantially lower; in the areas where there was no armed conflict, pro-Ukrainian sources of information were more widespread; and, in the periphery of the neighbouring regions, they already dominated the pro-Russian sources of information.

As a result, Internet users in those territories received a very different message about the understanding of the causes and consequences of the conflict as well as attitudes towards Kyiv or Moscow as centres or even broader geopolitical imaginations of international relations and Russia's role in the world politics.

\section{Geopolitical narratives of pro-Russian public pages and groups in Vkontakte}

Despite Pinkerton, A. et al. (2011) assumption that the Internet is of geopolitical concern due to uncontrolled and uncontrollable communication, Russian-Ukrainian conflict and representation of the events in Vkontakte show that SNS are of geopolitical concern also because of possible manipulations and controlled messages. Our study shows that in Russian SNS public pages and open groups there are no platforms for communication and exchange of ideas, but these are places of passive communication, where the source of information is just spreading messages to receiving subjects. On the one hand, they have no geographical barriers, but on the other, they are territorially bounded information spaces. For instance, pro-Russian pages and groups bound together people in 


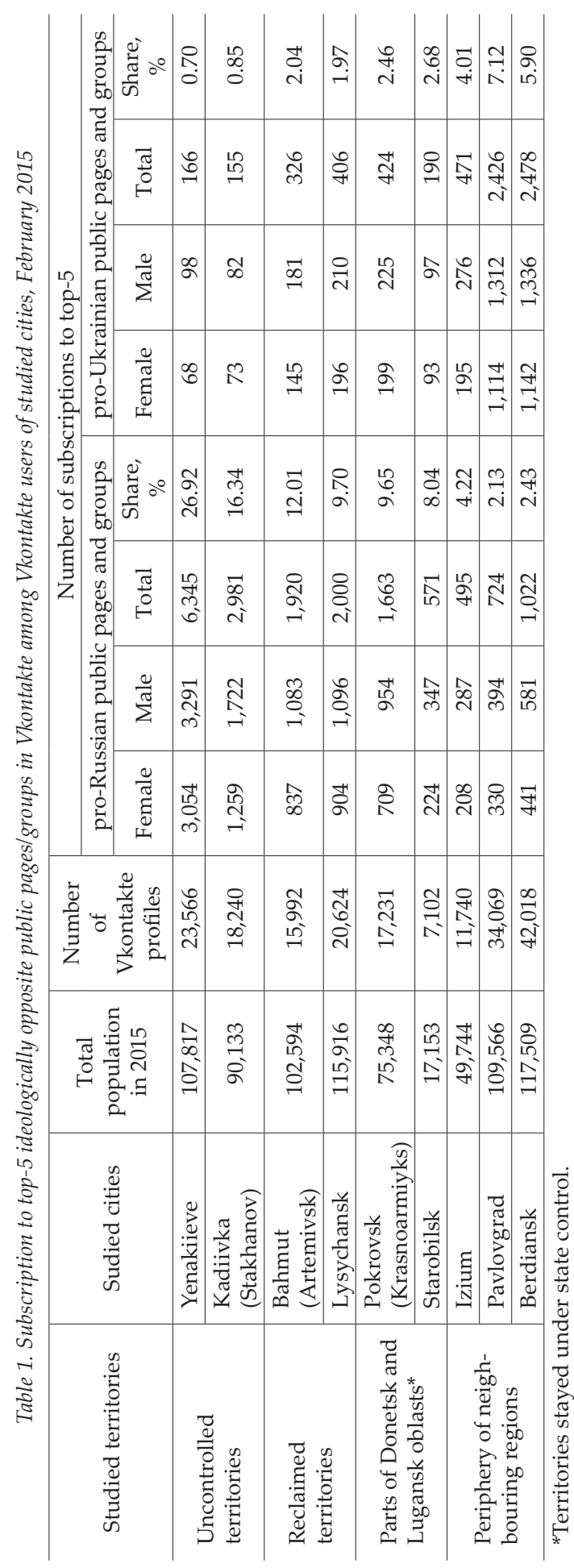

Russia and Donbass, while gradually separating Donbass from other South-Eastern, Central and Western Ukraine. Bourdieu's understanding of television (1998) as symbolical violence could also be used for public pages and groups in SNS as engaged in symbolical violence.

Antimaidan, pro-Russian, and proseparatists as a group of information sources for Russian speaking people of Ukraine were imposing specific geopolitical visions of the world and conflict in Eastern Ukraine. Content analysis of two of the five most popular pro-Russian pages in Vkontakte posts in 2015 shows that they were creating image of Ukraine as the Other, of South-Eastern Ukraine as a part of greater Russia, of the US and NATO as the main villains, and contradicting image of Europe: (1) negative, as "morally degrading" (in case when it was about Ukrainian inspirations of European integration), and (2) positive, as supporting annexation of Crimea and separatist inspirations in Donbass (mainly about particular positions of right, far-right and sometimes far-left political leaders) (Figure 6).

Narratives of Ukraine were oriented to discredit it as a state (notions of failed-state, oligarchs' domination, and weak and illegitimate government) and to accentuate its status as the Other for territories of the armed conflict ("karateli" [chasteners] image and notions of human rights violations). Use of "karateli" as a description of Ukrainian forces and almost everything connected to state apparatus was a crucial element of Russian propaganda in SNS. Important is an appeal to World War 2 memories because it is of high symbolical value for Russian and Ukrainian people. "Karateli" is a word that was used to describe Nazis and their Ukrainian collaborators who were killing local peo- 


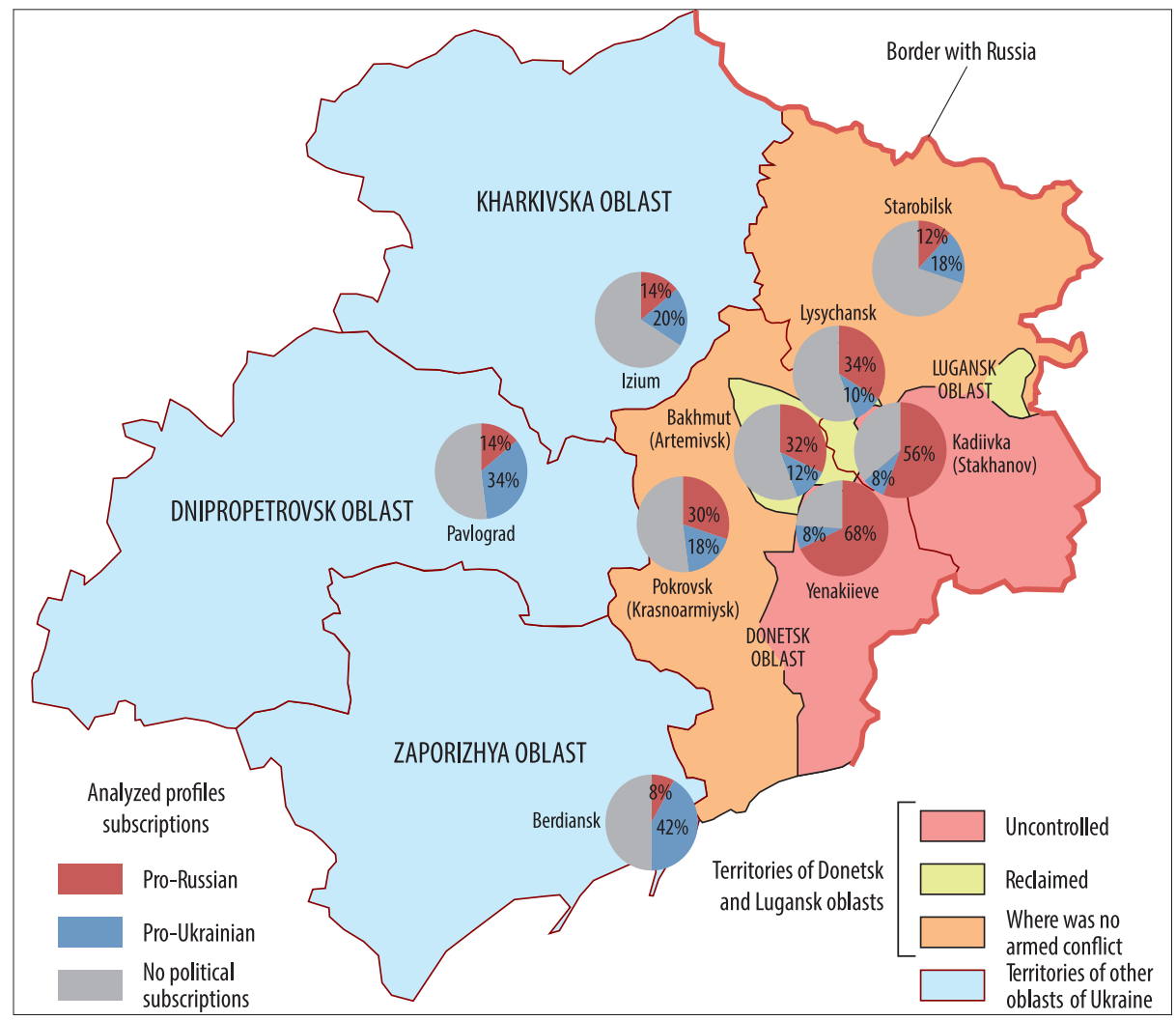

Fig. 5. Sources of information in social networking sites of Internet users from conflict territories and neighbouring regions.

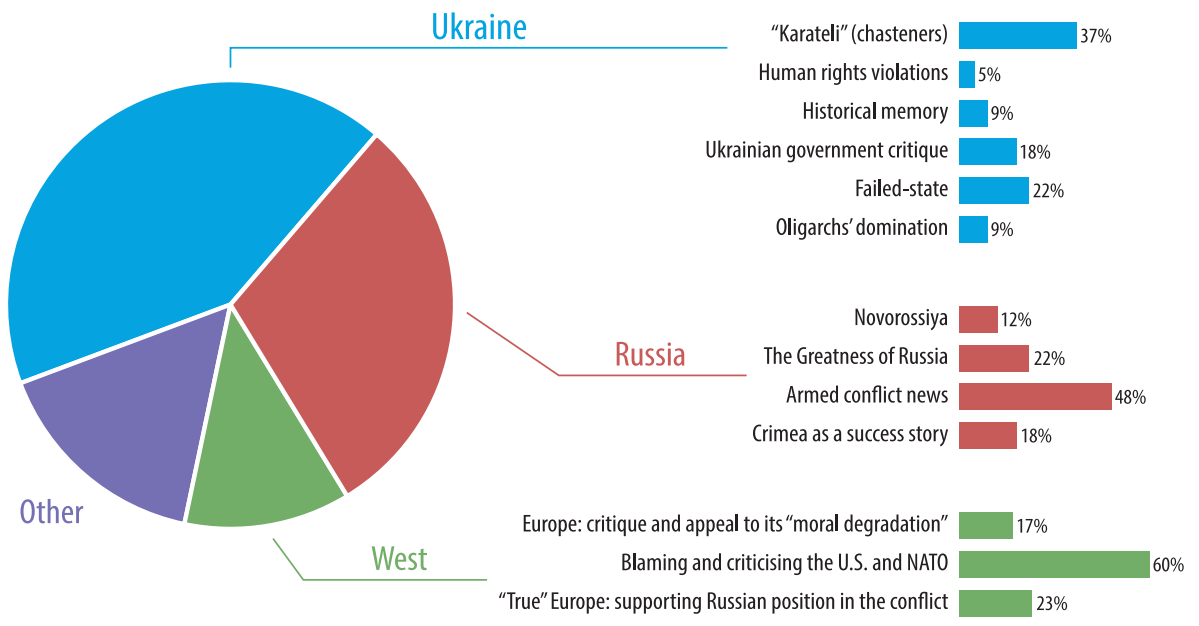

Fig. 6. Content analysis of "Antimaidan" and "Russkie online I Novorossiya" public pages in Vkontakte, 10-25 March 2015. 
ple in times of World War 2. Therefore, it was a strong emotional discrediting of Ukraine and the creation of Russia's image as a stronghold in a war with the enemy in the eyes of subscribers of Antimaidan and pro-separatist pages. Moreover, continuous appeal to Kyiv authorities ("Kievskie vlasti") as illegitimate and oppressing local populations in South-Eastern Ukraine was developing the image of Kyiv as the Other, while Moscow was portrayed as a centre, which can protect local populations from the violence of Kyiv authorities.

Narratives about Russia were complicated. First, armed conflict news were given not from neutral or only pro-separatist perspectives. They were following lines of official Russian Federation positions in the conflict. Second, the legitimization of Russian involvement in the conflict was often supported by the narrative of Slavic unity and Russian greatness. It supports conclusions of KASAMARA, V. and Sorokina, A. (2012) about imperial ambitions of the Russian population of different social statuses. The studied public pages in Vkontakte were creating particular geopolitical imaginations of Ukrainian territories in their connection to Moscow as a centre. For instance, Crimea annexation legitimization practices were built on notions of "reunification" and historical justice as well as stories of social and economic success after the annexation. South-Eastern Ukraine territories were described using the concept of historical "Novorossiya", which was undermining the role of Kyiv as a legitimate political centre for the region and accentuating its historical and cultural connections to Moscow.

Moreover, these narrative lines were supported by messages about Russian greatness, which included notions of a mighty army, reach natural resources, reach cultural heritage, influence on geopolitical scene, and ability to resist such world powers as the US, which was portrayed as the biggest enemy of Slavic people and "Russkiy mir", undermining post-Soviet space unity, and its economic and political capacities, provoking conflicts in Russia and its "sphere of interests". Geopolitical image of NATO was constructed using the same narrative. Notions of NATO and the US were used interchangeably, while the image of Europe in pro-Russian public pages in Vkontakte was constructed ambiguously. On the one hand, a number of messages in the analyzed content were criticizing Ukrainian inspirations for integration with the EU by portraying European states as "morally degrading", which in the narrative of pro-Russian public pages in Vkontakte means domination of liberal values which are contradicting traditional values of Russians and more broadly Slavic people. At the same time, they were developing a positive narrative of Europe using statements of European far-right, far-left, and pro-Russian politicians and activists.

\section{Conclusions and discussion}

Public pages in Vkontakte, which emerged as a reaction to the Euromaidan revolution in Ukraine and later armed conflict in Donbas, were producing broader geopolitical narratives and imaginations of different territories. For example, the image of Crimea as historically Russian land, South-Eastern Ukraine as "Novorossiya" culturally closer connected to Moscow than Kyiv, which was undermining the sovereignty of Ukrainian state and legitimation of Kyiv as a political centre for these territories. Second, these public pages were not just informing people about the conflict, but also suggesting a geopolitical vision of international relations. The United States and NATO were presented as main villains who caused armed conflict by interfering in Ukrainian politics, and Russia image was developed around its greatness as a prerequisite to oppose these enemies. Ukrainian government was discredited using "karateli" concept with the emotional appeal to World War 2.

The consumption of above described geopolitical imaginations and narratives in SNS had clear territorial differences in Ukraine. Subscription to top-5 ideologically pro-Russian public pages and groups in Vkontakte 
was predominant to the subscription to top5 pro-Ukrainian only in Donetsk, Lugansk, and Simferopol regional centers in Ukraine. In Odesa and Kharkiv, for each one subscription to pro-Russian pages were three subscriptions to pro-Ukrainian. Internet users in such cities of South-Eastern Ukraine as Dnipropetrovsk, Mykolaiv, Zaporizhya, and Kherson (whose voting behaviour in years of independence of Ukraine was mainly shifted to the pro-Russian side) in times of armed conflict in Donbas were predominantly using pro-Ukrainian sources of information in Vkontakte. It follows electoral behaviour patterns in 2014 presidential and parliamentary elections in Ukraine, which support the thesis that existing territorial differences in political beliefs are preconditions for the homogenization of subscription to information sources in SNS.

The study of the conflict zone Internet users information sources preferences reveals the influence of the emerged borders and administrative divisions. Cities in the occupied area and reclaimed by the Ukrainian army were using pro-Russian sources of information in Vkontakte more often than other cities in Donetsk and Lugansk regions where was no armed conflict and where Russiabacked separatists were not controlling territory for substantial time. At the same time, administrative borders between Lugansk and Donetsk oblasts on the one side, and Kharkiv, Dnipropetrovsk, and Zaporizhya on the other are vividly visible in the number of subscribers to pro-Ukrainian public pages and groups in Vkontakte.

On the one hand, existing territorial differences in political views frame behaviour of the users on the Internet. On the other hand, SNS as geopolitical tools could be used to polarize society along existing or imagined borders, mobilize people in conflict areas, and spread specific geopolitical narratives. Existing administrative divisions, phantom borders revealed by electoral campaigns, emerged borders of conflict zones frame Internet users' decisions about information sources on SNS. It corresponds with Borondo, J. et al. (2014) findings that Internet users cluster themselves in homogeneous groups. However, homogeneity could be based on conformity to a similar vision of the region or place regarding centre-periphery relations, causes of conflict, and a geopolitical picture of the region and the world. TAKHTEYEV, Yu. et al. (2012) findings that social ties in Twitter networks depend on the geographical distance between users and are stronger in similar metropolitan areas could have external validity for other SNS and coverage of conflicts in SNS.

The paper's findings show that people living in the same administrative regions of Ukraine and within newly emerged conflict zone boundaries use different sources of information about the conflict. Moreover, those sources of information are not only about agenda setting and coverage of the events but also spread broader geopolitical narratives about actors involved, centre-periphery relation, legitimation of the authorities, and a geopolitical picture of the world. However, we should admit that it does not suggest that all places within administrative borders are homogeneous. Intraregional variability is also of great interest to study in the context of the sources of information preferences in SNS, but it was not in the focus of this paper.

In the case of the post-Soviet space, where the Russian language is understood or even native for populations in the countries neighbouring to Russia, information distributed on the Internet is a powerful tool to promote pro-Russian geopolitical orientations among the local population. Territorial differences of such information consumption depend on existing territorial divisions. However, the reasons why some territories are more vulnerable to specific geopolitical narratives is still under question. These questions in the time of the increased importance of the securitization of cyberspace are of great interest for further geographical research. 


\section{REFERENCES}

Barrington, L.W. and Herron, E.S. 2004. One Ukraine or many? Regionalism in Ukraine and its political consequences. Nationalities Papers 32. (1): 53-86.

Bernazzoli, R.M. and Flint, C. 2009. Power, place, and militarism: toward a comparative geographic analysis of militarization. Geography Compass 3. (1): 393-411.

BIRCH, S. 2000. Interpreting the regional effect in Ukrainian politics. Europe-Asia Studies 52. (6): 1017-1041.

Borondo, J., Morales, A.J., Benito, R.M. and Losada, J.C. 2014. Mapping the online communication patterns of political conversations. Physica A: Statistical Mechanics and Its Applications 414. 403-413.

Bourdieu, P. 1998. On Television. New York, The New Press.

Clem, R.S. and Craumer, P.R. 2008. Orange, blue and white, and blonde: the electoral geography of Ukraine's 2006 and 2007 Rada elections. Eurasian Geography and Economics 49. (2): 127-151.

Conroy, M., Feezell, J.T. and Guerrero, M. 2012. Facebook and political engagement: a study of online political group membership and offline political engagement. Computers in Human Behavior 28. (5): 1535-1546.

Duvanova, D., Nikolaev, A., Nikolsko-Rzhevskyy, A. and Semenov, A. 2016. Violent conflict and online segregation: an analysis of social network communication across Ukraine's regions. Journal of Comparative Economics 44. (1): 163-181.

Duvanova, D., Semenov, A. and Nikolaev, A. 2015. Do social networks bridge political divides? The analysis of VKontakte social network communication in Ukraine. Post-Soviet Affairs 31. (3): 224-249.

Frame, A. and Brachotte, G. 2015. Le tweet stratégique: use of Twitter as a PR tool by French politicians. Public Relations Review 41. (2): 278-287.

Friedman, Th.L. 2005. The World Is Flat: A Brief History of the Twenty-First Century. Farrar, Straus and Giroux.

Gaufman, E. 2015. Memory, media, and securitization: Russian media framing of the Ukrainian crisis. Journal of Soviet and Post-Soviet Politics and Society 1. (1): 141-175.

Gemius 2015. Auditoria Uaneta. Retrieved on 7 March 2015 from: http://bit.ly/1wddVpA

Goldenberg, J. and Levy, M. 2009. Distance is not dead: social interaction and geographical distance in the internet era. Computers and Society 2. 1-22.

Helmus, T.C., Bodine-Baron, E., Radin, A., Magnuson, M., Mendelsohn, J., Marcellino, W., Bega, A. and Winkelman, Z. 2018. Russian Social Media Influence: Understanding Russian Propaganda in Eastern Europe. Santa Monica CA, RAND Corporation.
Jackson, L. and Valentine, G. 2014. Emotion and politics in a mediated public sphere: questioning democracy, responsibility and ethics in a computer mediated world. Geoforum 52. 193-202.

Johnston, R.J., Shelley, F.M. and Taylor, P.J. (eds.) 1990. Developments in Electoral Geography. New York, Routledge.

Kasamara, V. and Sorokina, A. 2012. Imperial ambitions of Russians. Communist and Post-Communist Studies 45. (3-4): 279-288.

Kasmani, M.F., Sabran, R. and Ramle, N. 2014. Can Twitter be an effective platform for political discourse in Malaysia? A study of \#PRU13. Procedia - Social and Behavioral Sciences 155. (October): 348-355.

Kruikemeier, S. 2014. How political candidates use Twitter and the impact on votes. Computers in Human Behavior 34. 131-139.

Liber, G.O. 1998. Imagining Ukraine: regional differences and the emergence of an integrated state identity, 1926-1994. Nations and Nationalism 4. (2): 187-206.

Lippmann, W. 2017. Public Opinion. New York, Routledge.

Lipset, S.M. and Rokkan, S. 1967. Cleavage structures, party systems, and voter alignments: an introduction. In Party Systems and Voter Alignments; Cross-national Perspectives. Eds.: Lipset, S.M. and RоккаN, S., Michigan, University of Michigan Free Press, $1-50$.

NAM, T. 2012. Dual effects of the internet on political activism: reinforcing and mobilizing. Government Information Quarterly 29. Supplement 1. 90-97.

O'Loughuin, J. 2001. The regional factor in contemporary Ukrainian politics: scale, place, space, or Bogus effect? Post-Soviet Geography and Economics 42. 1-33.

O'Loughlin, J., Toal, G. and Kolosov, V. 2016. Who identifies with the 'Russian World'? Geopolitical attitudes in Southeastern Ukraine, Crimea, Abkhazia, South Ossetia, and Transnistria. Eurasian Geography and Economics 57. (6): 745-778.

Osipian, AL.L. 2015. Historical myths, enemy images, and regional identity in the Donbass insurgency (Spring 2014). Journal of Soviet and Post-Soviet Politics and Society 1. (1): 109-140.

Osipian, Ar.L. and Osipian, AL.L. 2012. Regional diversity and divided memories in Ukraine: contested past as electoral resource, 2004-2010. East European Politics \& Societies 26. 616-642.

PARK, С H.S. 2013. Does Twitter motivate involvement in politics? Tweeting, opinion leadership, and political engagement. Computers in Human Behavior 29. (4): 1641-1648.

Peisakhin, L. 2013. In history's shadow: do formal institutions leave a cultural legacy? Barcelona, EPSA 2013 Annual General Conference Papers, No 286. Available at: https://papers.ssrn.com/sol3/papers. cfm?abstract_id $=2224765$ 
Pinkerton, A. and Benwell, M. 2014. Rethinking popular geopolitics in the Falklands/Malvinas sovereignty dispute: creative diplomacy and citizen statecraft. Political Geography 38. 12-22.

Pinkerton, A., Young, S. and Dodds, K. 2011. Weapons of mass communication: the securitization of social networking sites. Political Geography 30. (3): 115-117.

Simons, G. 2015. Perception of Russia's soft power and influence in the Baltic States. Public Relations Review 41. (1): 1-13.
Steenkamp, M. and Hyde-Clarke, N. 2014. The use of Facebook for political commentary in South Africa. Telematics and Informatics 31. (1): 91-97.

Takhteyev, Yu., Gruzd, A. and Wellman, B. 2012. Geography of Twitter networks. Social Networks 34. (1): 73-81.

Wang, D.M., Costa, E., Haynes, N., McDonald, T., Nicolescu, R., Sinanan, J., Spyer, J., Venkatraman, S. and NyuAN, X. 2016. How the World Changed Social Media. London, UCL Press. 